\title{
Hypotheses about Geoglyphs at Nasca, Peru: New Discoveries
}

\author{
Jaroslav Klokočníka , Karel Pavelkab ${ }^{\mathrm{b}}$, Jiří Sonnek ${ }^{\mathrm{c}}$, Karolína Hanzalováb \\ ${ }^{a}$ Astronomical Institute of the Academy of Sciences of the Czech Republic, \\ Ondřejov Observatory \\ ${ }^{b}$ Dept. of Geomatics, Fac. of Civil Engineering, CTU in Prague, Czech Republic \\ ${ }^{\mathrm{c}}$ Koroze, Hlučín, Czech Republic \\ jklokocn@asu.cas.cz, pavelka@fsv.cvut.cz, koroze@volny.cz
}

\begin{abstract}
The known hypotheses about the reasons why the geoglyphs in the Nasca and Palpa region of Peru were created are many: roads/paths, rituals/ceremonials, use of hallucinogens, astronomical meaning, influence of extraterrestrials, underground water... and so on. We present a new hypothesis, formulated by J. Sonnek (first published in 2011) in the context of all previous hypotheses [17]. Sonnek explains the geoglyphs as tidied work areas for the production of rope and nets, although he goes much further than Stierlin. This eccentric hypothesis now has not only experimental but also archaeological and ethnographical support, which is presented here. Geoglyphs of a special shape were discovered in the pampas; they may represent technical objects - different types of 'rope twisters'. Following this idea, Sonnek made technical devices (using today's materials) and tested them in practice; they work perfectly, see his YouTube videos [15, 16]. In November 2012, wooden pieces, which may be the remnants of ropemaking, were collected from the pampa near the towns of Nasca and Palpa, in vicinity of these hypothetic ropemaking places. Radiocarbon testing by ${ }^{14} \mathrm{C}$ standardized radio-carbon age according to Stuiver-Polach convention and Accelerator Mass Spectroscopy (AMS) of these wood pieces shows the age to be in a wide range from Early Nasca to the $1^{\text {rth }}$ century (and to our epoch with a fake geoglyph, too), thus supporting (but surely not proving) the new hypothesis. Moreover, in the Quechua language, the word huasca, waskha (read: uasca) means a rope or cord or place where these are produced. This word is very similar to 'nasca'.
\end{abstract}

Keywords: Geoglyphs, Nasca, Peru

\section{Introduction}

The geoglyphs (figures and geometrical shapes) on the pampas (desert) near the town of Nasca and nearby town of Palpa in Peru have long been known to our civilization, since the research of Toribio Mejia Xesspe (see $[9,12,21]$ ) and the beginning of commercial flights from Lima to southern parts of Peru, which have attracted the attention of both scientists and 'independent researchers'. The geoglyphs were mostly made by the Nascanian people by removing the dark surface layer of the desert varnish (the weathered and oxidized thin top layer) to reveal the pale, 'sandy' subsoil.

The figures and geometrical shapes were preserved because the area receives very little rainfall (excluding episodes of El Niño). There are also other geoglyphs in various places in South 
America, mostly near the Pacific coasts of Ecuador, Peru and Chile.

A number of hypotheses about the reasons for construction of the glyphs have been suggested. We will comment only on the main hypotheses $[2,3,5,9,12,13,14,19,21]$. None of them have generally been accepted, to date. We also present here a new, very unusual and 'technical' hypothesis, that of Sonnek [17]. It does not contradict most of the preceding hypotheses, but brings a practical perspective for the reasons why the geoglyphs were made. We provide supporting arguments for the validity of this new and surprising hypothesis.

\section{Note on previous hypotheses}

Here we cannot (due to space reasons) explain all the existing and widely acknowledged work done by Xesspe, Kosok, Reiche, Silverman, Schreiber, Browne, Clarkson, Aveni, Urton, Lambers, Ruggles, Teichert, Richter and others, who discuss the geoglyphs in an Andean and landscape context. For example, Kosok studied irrigation systems in Peru. He took a famous photograph of sunset at their winter solstice from a single ray centre (on a small local hill), running along one of the ray lines. Kosok was inspired and formulated an astronomical hypothesis, which was adopted soon after that by Ms Reiche; in due course, her followers from Dresden (Teicher, Richter and others), also supported the hypothesis. Kosok, Hadingham and others also recognized the importance of the ritual/ceremonial meaning of the geoglyphs, including pleas to the gods for water [3]. The geoglyphs may have a relation to groundwater, this has been investigated by several authors [14]. The geological faults in the mountains supply drinking water to aquifers, from which it can be directed to users. Johnson $[5,6]$ shows a correlation of aquifers, geoglyphs and former human settlements (now cemeteries). The hypothesis formulated by Stierlin explains the geoglyphs as the remnants of giant open-air workshops where weavers produced fabrics in a manner similar to the use of a loom [19].

\section{Outline of the new hypothesis}

The geometrical geoglyphs on the Nasca plateau are traces left behind by the manufacturing plants of ropemakers, who produced here the required range of ropes and probably also nets for fishermen, raft makers, buildings and bridges, claims Sonnek [17]. Before beginning production, the ropemakers tidied the area as needed. They laid ropes defining the working area on the ground, and removed rocks and gravel from it to prevent the ropes and nets from damage during production. They then installed poles for hanging the ropes produced in the working areas. The narrow triangular sectors (trapezoids) are remnants of the landscaping for the ropemaking; the rectangular areas were used for net production. The trapezoids and the long lines crossing them in a zigzag fashion are the places where long ropes were made in as small area as possible. The geoglyphs were produced in the course of centuries and they indicate new working areas frequently overlapping older ones. The working areas run in all directions.

The orientation of the work areas was dictated by available land and sometimes they were actually set up to make use of ground undulations or hills. Landscaping for some of the giant geoglyphs might be laborious, so it is not out of the question that they may have performed additional functions as well (for example for ceremonial purposes). Today a multifunctionality of the geoglyphs is generally accepted.

Sonnek considers the geoglyphs in the shape of animals and various symbols running out 
of the work areas to be logos ('totems') and advertisements of the different ropemaking workshops [17]. The fish, the fisherman with a fish in his net, the dolphin, shark, sperm whale, killer whale and coiled rope are all very apt for rope and net manufacturers. The spirals and the monkey with its tail coiled in an identical spiral may be representations of coiled rope, excellent logos for the makers of strong ropes. We note that this is a speculative item in the Sonnek hypothesis. Zoomorphic and other shaped features may be older than the geometric shapes and may belong to category of geoglyphs created primarily for rituals (as for conversations with A. Rodriguez, Lima, in 2001) or for another use [14].

Making the geoglyphs was not a technical problem; the ropemakers used what they always had at hand: rope. Small-scale drawings on a template were intentionally stylized into simple forms made of a single continuous line, so that they could be rendered to the chosen scale using rope laid on the ground. The rounded edges of the figures make this clear and quite logical. An easy-to-see rope could have been overseen outside a portable tripod several metres high, each section aligned to position as instructed by the overseer, and then only the dark surface layer of ground was removed on one side of the rope. This simple technology accounts for some of the inaccuracies in the figures. Tightening the rope on the ground was enough to define the working triangles and rectangles.

Why Nasca and Palpa were selected for the ropemaking? There are many areas suitable for this purpose along Peruvian coast, and probably were used too, but the Nasca/Palpa area had very appropriate meteorological conditions (very dry). The geoglyphs may suffer from El Niño or human activities, but a huge number of them survived to the present day. The place to produce them must have been a sufficiently large flat area without vegetation, at a higher altitude where it is not dramatically hot and is without rain but with underground potable water nearby, not too far from the sea, and near the fertile valleys where henequen (maguey, species of agave) and similar material for ropemaking and food for the ropemakers could be grown. Nobody would have allowed ropemakers in the fertile areas, where food for all could be grown.

The important fact is that the new hypothesis is not in conflict with the older ones - this is not typical for previous hypotheses. It is highly possible that certain lines were created with intentional astronomical meaning as well as practical utility, nor is a combination of practical use with a ritual/ceremonial meaning ruled out. As for the existence of drinking groundwater, its proximity was certainly welcome by the ropemakers and influenced their choice of the appropriate places to set up work areas. It is not a problem for the newly presented hypothesis to explain the diverse directions of the geoglyphs, their overlapping in all directions or their presence in areas with underground water.

\section{Proof-of-concept tests}

Sonnek performed various experiments to support the new hypothesis. A geoglyph of a very special shape was discovered in the pampa, see Figure 1a; it may represent a technical object, let us call it a rope twister. Following the pattern shown in Figure 1a, Sonnek made a steel technical device and tested it in practice, see Figure 1b; a video of Sonnek's experiment is available on You Tube $[15,16]$. This does not mean that this is the only possible technical solution for the ropemaking. Due to course variants, other fittings were discovered and tested, again this can be seen on Sonnek's You Tube videos. 
Four spun threads, connecting the pole at the tip of the triangular sector and the rope twister installed in the wooden skid frame, twisted to the right. The twisting reduces the thread length, so that the skid is pulled towards the pole at the end of the line and keeps the twisted threads tight. This first twisted strand had to be attached to a prepared pole; otherwise, it would untwist and produce kinks. Three more strands were twisted in an identical fashion and then all the four, right-twisted strands were again fastened to the twister lugs. By now twisting to the left, we produced rope that no longer came untwisted. The left twisting reduced the length of the rope, meaning the final rope is $8-30 \%$ shorter (depending on the rope diameter) than the threads before twisting. Our experimental twisting of ropes of various thicknesses, using the twister, not only confirmed the perfect functionality of the device, but also led to several interesting findings.
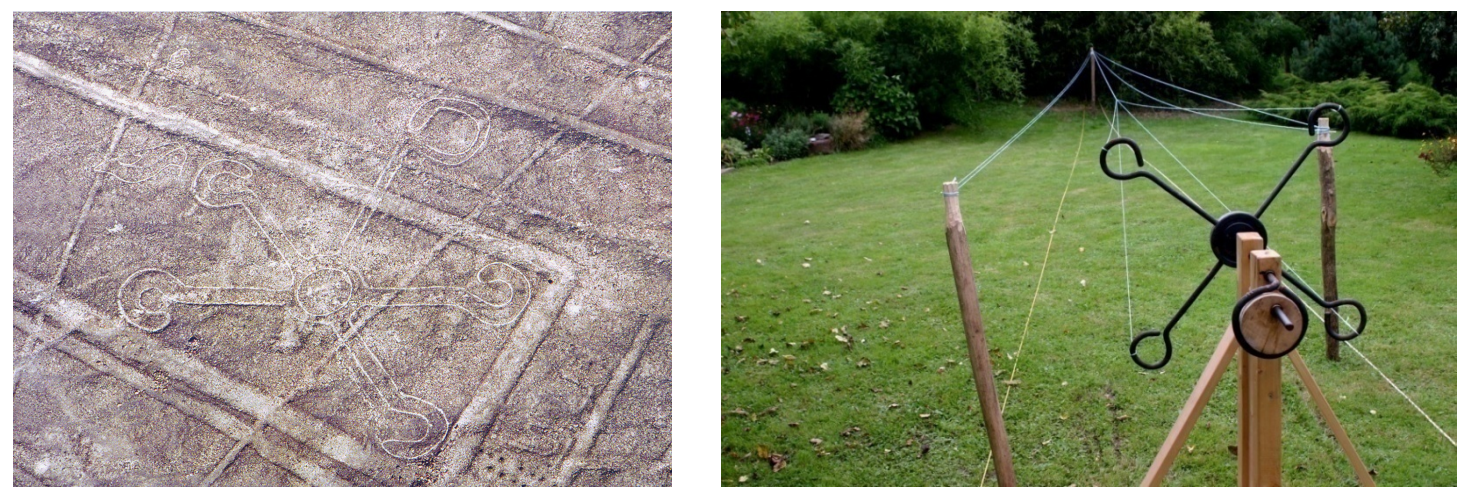

Figure $1 \mathrm{a}$, b: Left: a technical object-one geoglyph on the pampa. (C) Google Earth: geographic latitude $\varphi=14^{\circ} 33^{\prime} 32^{\prime \prime} \mathrm{S}$, longitude $\lambda=75^{\circ} 10^{\prime} 40^{\prime \prime} \mathrm{W}$. Right: a functional model of a rope twister made from metal (in a convenient size) after the geoglyph on pampa (a), for experimental rope making. The original material may have been hard wood. () J. Sonnek, 2013.

Figure $1 \mathrm{~b}$ shows the twisting of the third strand (as an example). The pole on the right already has two twisted strands on it, and the pole on the left has threads ready for twisting of the fourth strand. The lengths of string lying on the ground are representations of the definition of a work area, rid of gravel and stone on the pampa. The threads are pulled on the ground when being extended, meaning the work area has to be swept perfectly clean; otherwise, the threads might get damaged or torn. The runners of the travel devices also require a smooth surface. The length of the crank arm, whence the proportion of the rotation speed and the required force, is easily adjusted by tapping out and rotating the wooden pad with the crank. The right-hand side pole, for fastening the twisted threads, is where the first travel of the twisting device ends. It has to be by the edge in order to stand clear of the further travel of the skid. An inspection of the narrow work areas using the satellite has confirmed, in many cases, traces of an identically situated pole and a pole at the narrow end of the work area. Moreover, the areas bear visible traces of another pole, near the start of the work line (the left-hand side pole). What was it good for? Already while one person was twisting the rope, another was extending new threads for twisting additional strands between this pole and the end-of-line pole. After the skid was pulled back to the start, the prepared threads were simply transferred from this pole to the twister hooks, with no time delay and loss of productivity. The robust twister lugs have a purpose: they serve as a flywheel, which 
allows the operator to rest for a while after getting it spinning.

The string threads may lie on simple racks, which keep the threads apart. No landscaping at all is required for this production procedure. The string being produced will be a little saggy between distant racks, but that does not prevent it from continuing through the rolling terrain in a straight line. This explains the longest straight lines found on the plateau. The ropemakers many times repeated 'ambles along the stretched strings' resulted in pale lines on the ground: the numerous traces across the plateau. They are more prominent along the edges, because the makers would walk on either side of the strings being made, and they are not as accurately straight as those created artificially.

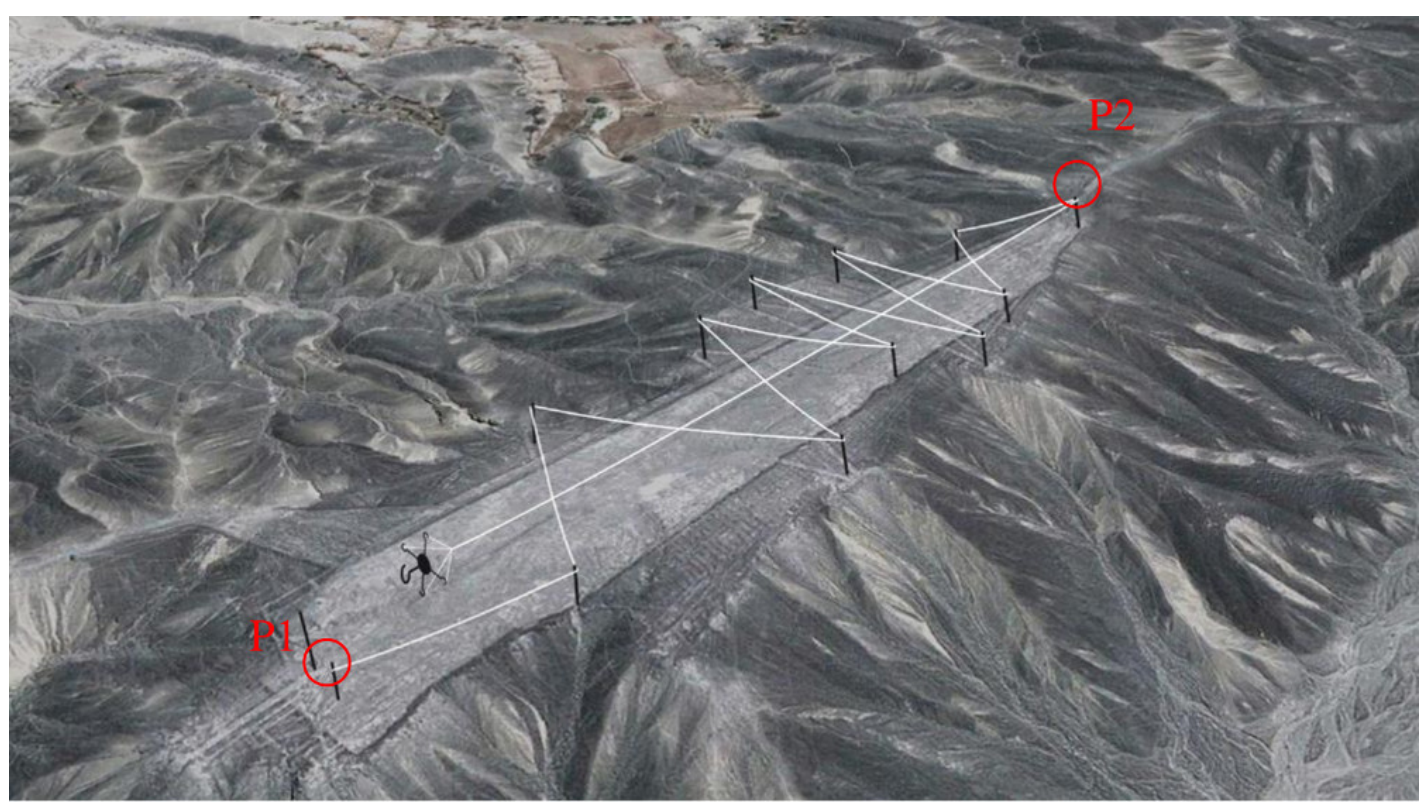

Figure $2 \mathrm{a}$ : Work area near the ropemakers' homes (here near town now known as Palpa). Large trapezoid at $\varphi=14^{\circ} 33^{\prime} 54^{\prime \prime} \mathrm{S}, \lambda=75^{\circ} 11^{\prime} 33^{\prime \prime} \mathrm{W}$, one of the places where pieces of wood for the ${ }^{14} \mathrm{C}$ test were collected in 2012. Snapshot by @ G Google Earth. Drawn by @ J. Sonnek. The circles P1 and P2 show locations of two of wood remnants tested (see table below). More than one instrument may work simultaneously there.

Let us take a look at a work area for ropemaking with a higher productivity (Figure 2a). The broad area at the centre was used as the work area for the twisting devices. The rope threads did not continue in a straight line as usual, but were turned left twice by $\sim 90^{\circ}$ around poles to the opposite direction, and then once again. The start and end of the threads were side-by-side before the twisting operation. A small flat area thus could be used for both short and long pieces of rope, as required, and the movements of the persons extending the threads became more efficient: they did not have to return long distances, everything being at hand.

They are numerous complex figures (trapezoids with zigzags) in the Nasca-Palpa area. Figure 2a shows a trapezoid with a zigzag near Palpa (sometimes called 'Pista'). Figures 3 a, b, and c (below) show a part of series of such geoglyphs in Cantalloc near Nasca (the name 'cantalloc' means 'place of weavers'). Such glyphs contain many technical details (e.g., Figures 1a or 3b).

Based on the traces left, Sonnek set up a similar work area for string production and tested 


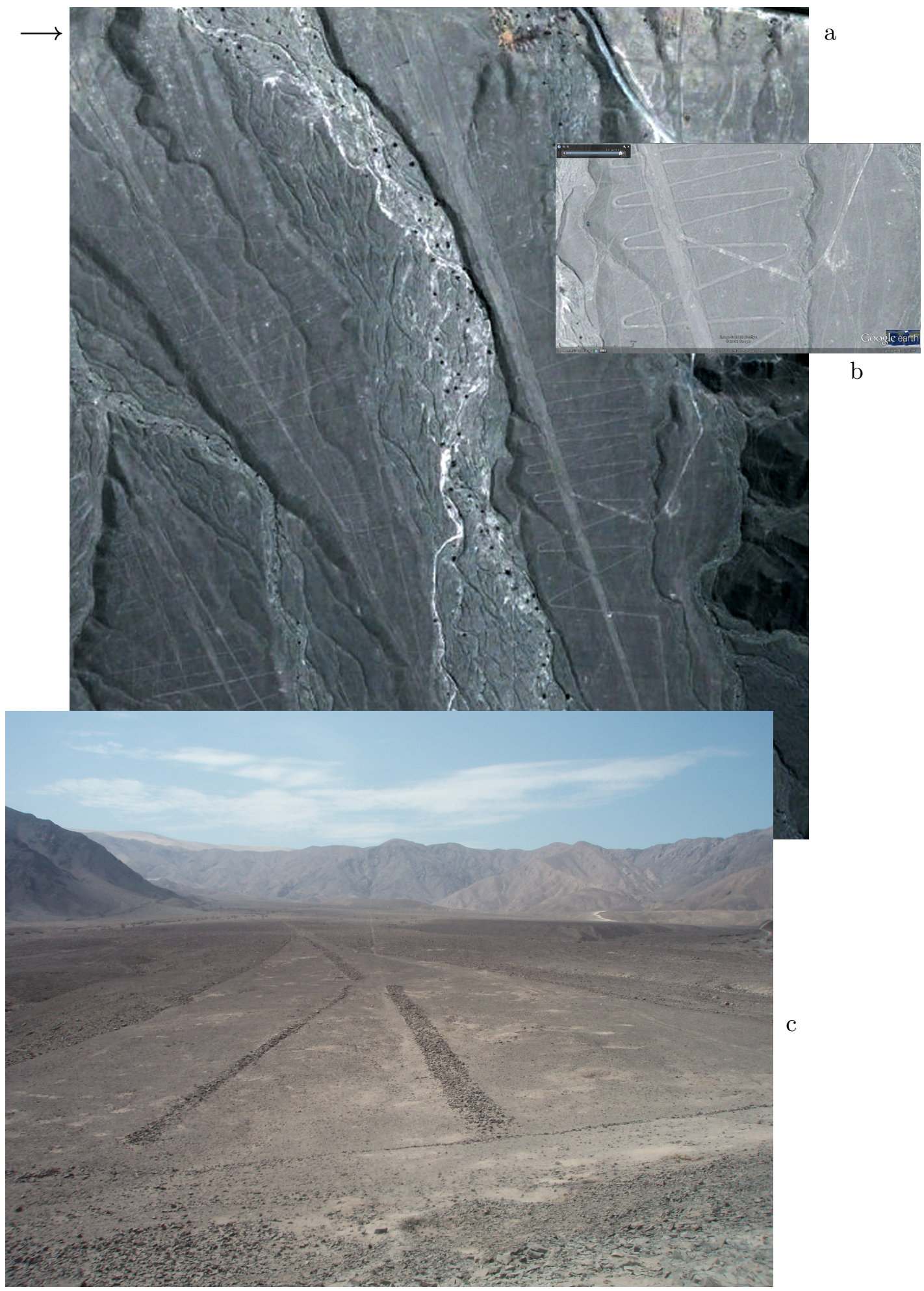

Figure $3 \mathrm{a}, \mathrm{b}, \mathrm{c}$ : (a) Work areas near the ropemakers' homes (Cantalloc near Nasca) were advantageous for their easy accessibility. () Google Earth: $\varphi=14^{\circ} 50^{\prime} 09^{\prime \prime} \mathrm{S}, \lambda=74^{\circ} 54^{\prime} 08^{\prime \prime} \mathrm{W}$. Inserted small figures: (b) a detail of zigzags; (c) ground photo from the same place indicated by the arrow in (a). Photo @ J. Klokočník, 2011. 
its functionality. The functioning device (our model) had to leave traces (Figure 2b) identical to those left on the pampa (see Figure 2a). The installed device makes it possible to produce very long ropes in a small area. This is because the rope does not continue forward in a straight line but rather returns to the start of the work line, hung on poles where the long zigzags turn. This technology allows the production of rope lengths several times longer than the flat area available. Over time, paths similar to those at Nasca-Palpa were trodden in the grass around the poles in the experimental work area. The Nasca people were more foresighted: they tidied up their paths before they started twisting, by removing stones and gravel.

The more laborious rope production (assistants had to turn the rope around the poles in the zigzag turnings with their palms, Figure 2c) was compensated for by easy access and other advantages. Traces left in the terrain indicate how the work areas improved over time. The flat area is optimally utilized and the work area is designed to allow the production of the longest string possible. The narrow work triangle for the travel of work devices is $800 \mathrm{~m}$ long and makes use of the entire length of the appropriate work area. The rope may be reduced in length by the length of the work triangle; the twisting device would hit the pole at the end of the line if any longer rope was made. The spiral logo connects to the geometric lines where the completed ropes end. Due to insufficient flat area, it is situated so that it partly interferes with the triangular work area in a place where it presents no obstacle. The zigzag spanning the entire flat area is the tidy path around the forked poles on which the rope threads were hung. It was traversed by the ropemakers while extending the threads and turning the rope. All the poles were installed on the inside of the path turnings.

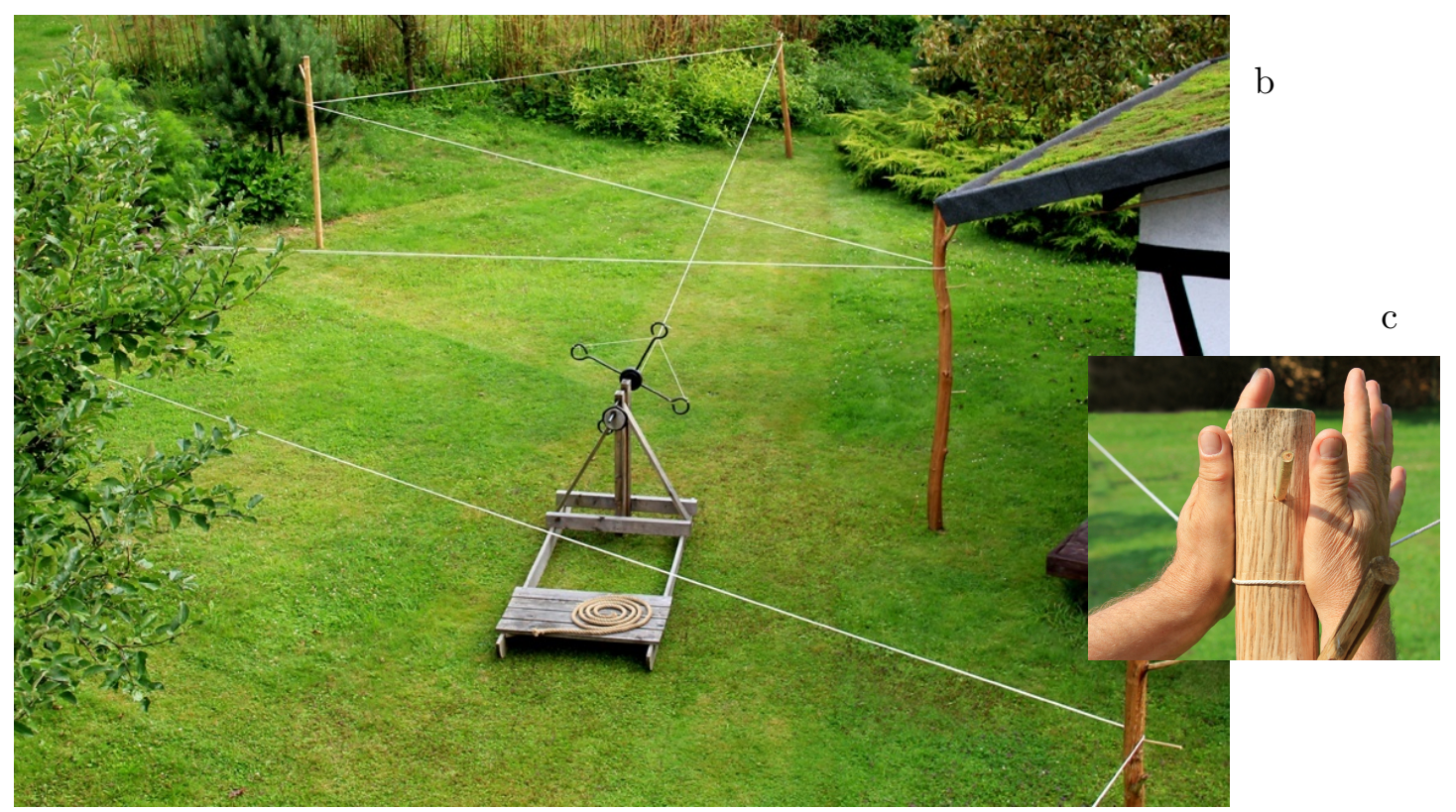

Figure 2 b, c: One of Sonnek's experiments (C to make a long string, using a device inspired by the geoglyph discovered on pampa (shown in Fig. 1a); (c, right) the rope at the turning point. 


\section{Further support of the new hypothesis}

1. One of huge geoglyphs on pampa near the Nasca town is well known as 'El Astronauto' (his right hand is thought to be directed to the sky). It has been demonstrated that this glyph shows most probably a fisherman $[7,8,18]$. His right hand is not directed to the sky, but holds a fishnet. The fisherman fits in that area - with its fish and agricultural product exchange between sea shore and mountains - much better than an astronaut (but it is not so attractive for the local 'tourist industry').

Sonnek and Klokočník interpret this geoglyph as a fisherman on a raft on open sea with his head covered with large hollow calabash (gourd, calabaza), a winter squash (Cucurbita moschata) that resembles a pumpkin and is typically grown in the West Indies and tropical America [10]. It has various usages at home. Here, a dried calabaza serves as practical weather helmet (like styrofoam-polystyrene). When experimenting with the temperature inside a wet calabash, Sonnek registered a cooling of the interior by up to $6^{\circ} \mathrm{C}$ due to water evaporation, for half an hour. Other components on the scene are a fish, a net, rope/net folded, and a cormorant, useful for fishing [7].

2. A small Czech expedition team visited the Nasca (Cantalloc) and Palpa area (Pista, Mandala) in November 2012 and collected wooden pieces, including possible remnants of poles at the zigzags. Radiocarbon dating of these woods shows a wide age range from early Nasca to the $17^{\text {th }}$ century, thus supporting the new hypothesis. For more about these new results see the text and table below.

3. The Nasca people mostly cultivated maize, beans and pumpkins. Their farm products travelled towards the sea; the fish went from the sea to the mountains. This is known as the local 'vertical trade exchange'. A need for large quantities of rope and nets is connected with the intensive fishery in the Pacific Ocean, which had to compensate for insufficient farm production. The Nasca people would set out on their rafts for voyages of maybe several months, heading for distant fisheries and islands. This intensive fishing at large distances from the coast required entire fleets of balsa-wood rafts and huge amounts of various ropes and nets.

It follows from the experimentally tested time for producing rope that it would take four working days to produce a $400 \mathrm{~m}$ length of rope; making the string for a suspension net measuring $350 \mathrm{~m}$ by $10 \mathrm{~m}$ with a mesh of $5 \times 5 \mathrm{~cm}$ could have taken 140,000 hours, i.e., approximately 600 days of 12 hours of work per day. Thus, there must have been a great many string suppliers for each manufacturer of such nets.

4. We still need to make the rope for tying up the balsa-wood raft and the deck $(500 \mathrm{~m})$, to fasten the mast $(100 \mathrm{~m})$, the anchor rope $(100 \mathrm{~m})$, and the hooked dip line $(300 \mathrm{~m})$; this is a total of about $1000 \mathrm{~m}$ per raft, excluding the nets. With an average crew of 30 per raft, this would require ropes and nets for about 670 rafts to be produced in a short time. But rope made from natural materials is subject to rot, so it had to be renewed. The construction industry, as well, consumed some quantity of strong rope. The aforesaid indicates that the number of manufacturers on the Nasca plateau corresponds to the period's needs and requirements.

5. The finished ropes were moved, probably dragged out on the pampa, by human power or perhaps with the aid of llamas - we can only speculate - from the field manufacturers 
to rivers or the seashore; traces of these displacements - footprints, lines, grooves - are traceable on the pampas, e.g., by means of Google Earth. Reader can view one of such paths, perhaps ancient, starting from $\varphi=14^{\circ} 42^{\prime} 12^{\prime \prime} \mathrm{S}, \lambda=75^{\circ} 10^{\prime} 32^{\prime} \mathrm{W}$ in the vicinity of geometric geoglyphs, and via $\varphi=14^{\circ} 42^{\prime} 55^{\prime \prime} \mathrm{S}, \lambda=75^{\circ} 11^{\prime} 57^{\prime \prime} \mathrm{W}$ to $\varphi=14^{\circ} 43^{\prime} 25^{\prime \prime}$ $\mathrm{S}, \lambda=75^{\circ} 13^{\prime} 09^{\prime \prime} \mathrm{W}$ near a river valley; other traces approach from north of Baha San Nicolas near Puerto San Juan (Pacific ocean), $\varphi=15^{\circ} 18^{\prime} \mathrm{S}, \lambda=75^{\circ} 10^{\prime} \mathrm{W}$, partly following a present-day road.

6. In the old Quechua language (or family of languages, existent perhaps since $900 \mathrm{BCE}$ ), the word huasca, wasca, waskha [read: uasca] means a rope or cord (or the place where these are produced). This word is very similar to the word 'nasca' [10]. Another view is from Teofilo Laime Acajopa, who considers that 'nasca' derives from 'anti' [1].

\section{Some details about radiocarbon age of wood fragments collected from the Nasca-Palpa area}

The samples have been collected near Nasca and Palpa, mostly from places related to Sonnek's hypothesis (see the circles in Figs. 2a, 4a and 4b). In one case - that of new fake, falsified geoglyphs (a Mandala) - the fact that this is a fake is known thanks to a comparison of old and new photos. Old photos are from archive of Maria Reiche (from around WWII). Few samples are shown in Figs. 4c,d and these are listed in the table below.

Dating was performed independently by two methods and two institutions: the standard ${ }^{14} \mathrm{C}$ method at the Institute of Nuclear Physic, Czech Academy of Science in Prague, the Czech Republic, and the AMS method (Accelerator Mass Spectroscopy) in Hekal Atomli HAS, Debrecen, Hungary [20, 4, 11]. The Radiocarbon Calibration Program (Stuiver, Reimer, () 1986-2015) was used; the dating is presented always within two sigma ranges $(2 \sigma)$.

All samples were checked and mechanically cleaned after being taken to the specialised laboratory. The samples were pre-prepared in solutions of $4 \% \mathrm{HCl}$, repeatedly in $4 \% \mathrm{NaOH}$ and then again in $4 \% \mathrm{HCl}$, known as pre-treatment procedure Acid / Alkali / Acid (A/A/A, or $\mathrm{ABA}$ ). All samples processed by the conventional procedure were combusted in a stream of pure oxygen (purity 5.0) in a quartz device. Acquired $\mathrm{CO}_{2}$ was prepared by wet purification using an $\mathrm{AgNO}_{3}$ solution and dried. Synthesized benzene was measured in a liquid scintillation spectrometer (Quantulus 1220). As a blind (fossil) sample, commercially available benzene (from Sigma-Aldrich, Spectrophometric grade) was used. The ${ }^{14} \mathrm{C}$ measured activity was expressed in years BP (Before Present) as conventional radiocarbon age according to the Stuiver-Polach convention. Combined uncertainty of the conventional radiocarbon age includes partial contributions of the measurement blind sample, calibration on the quenching effect and determining values of $\delta{ }^{13} \mathrm{C}$. Uncertainty values reported for conventional radiocarbon age of samples correspond to a probability of approximately $68 \%$.

After assigning uncertainties, the given adequate radiocarbon calibration curve, conventional radiocarbon age and its combined uncertainty were converted to the intervals of calibrated age (see the Table below; uncertainty interval $2 \sigma$ of ${ }^{14} \mathrm{C}$ activity corresponds to $95 \%$ probability). The overall rate of absolute probability $P$ of that calibrated age interval is based on the expanded uncertainty of the determination of ${ }^{14} \mathrm{C}(2 \sigma)$ and was calculated from the rate of relative probabilities main sub-set calibration program multiplied by a coefficient of 0.95 . 


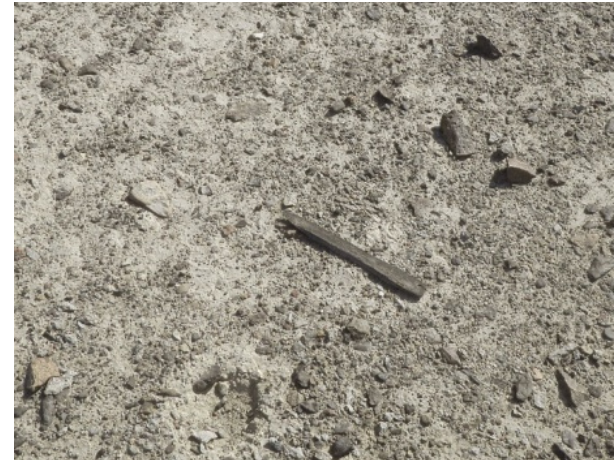

P2

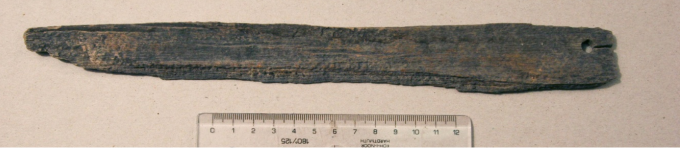

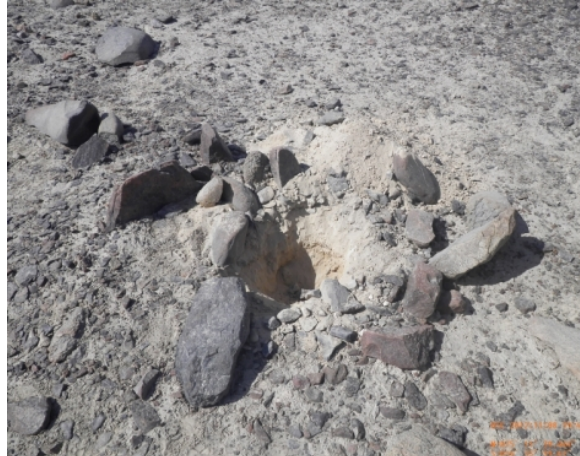

P1

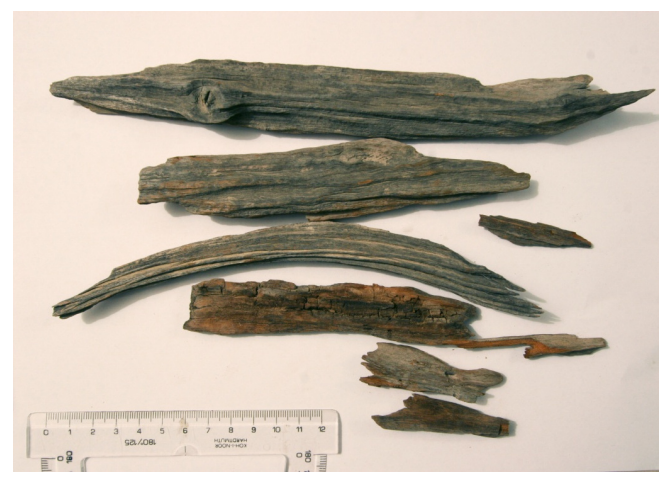

c d

Figure $4 \mathrm{a}, \mathrm{b}, \mathrm{c}, \mathrm{d}$ : Places P1 and P2 (Fig. 2a) where two of wooden splinters were found on pampa (one example, with an opening is in Fig. 4c). Photos ( K. Pavelka, 2012.

The analyses can be interpreted as follows:

a) The sample 13-097 comes from the post-Hispanic period. The dating is relatively broad, but started in $17^{\text {th }}$ century. It is probably part of a larger object (a wooden splinter containing an artificial opening).

b) The samples from Pista geoglyph and geoglyphs near today's Palpa cemetery (13_098 and 13_099) are made of huarango (guarango) wood and are old (pre-Hispanic period). They were collected near small pits, residues from the beginning of geoglyphs. Both samples are from the same period. Dated wood thus grew as trees most probably in the late $14^{\text {th }}$ century. Found and dated remains are probably splits from original equipment, tools or structures. How else would wood remnants get onto barren plains, away from dwellings, and why?

c) the samples from s/c Mandala geoglyph (13_101 and 13_102) are from cane or thin wood bars and they are dated to the 1960s and 1970s (bars were used for possible stakeout of geoglyph and are still a part of it - the evidence that it is a fake). The origin of these samples is clearly from the period after the initiation of nuclear weapon testing and for the dating it was therefore necessary to use a 'bomb' calibration curve for the corresponding region of the southern hemisphere (but it is a standard now).

d) the sample 13_103 from the destroyed settlement near Cantalloc is very old (it corresponds to a catastrophic flooding accompanied to El Niño in the fourth century CE). It is 
Table 1: ${ }^{14} \mathrm{C}$ age derived for samples gathered on pampa near the towns of Nasca and Palpa, Peru, in 2012. In the 'calibrated age' we have results from the first method (the standard dating) and in brackets there is the age estimate (with $2 \sigma$ ) from the AMS (if available).

\begin{tabular}{|c|c|c|c|c|}
\hline Sample & Description & $\begin{array}{l}\text { Conventional } \\
\text { radiocarbon } \\
\text { Age }(\mathrm{BP})\end{array}$ & $\begin{array}{l}\text { Calibrated } \\
\text { age }(\mathrm{CE})\end{array}$ & $\begin{array}{l}\mathbf{P}(\%) \\
\text { probability }\end{array}$ \\
\hline 13_097 & $\begin{array}{l}\text { Nasca Palpa, } 1, \\
\text { geoglyph Pista }\end{array}$ & $76 \pm 88$ & $\begin{array}{l}1666-1783 \\
1796-1949 \\
1666-1949\end{array}$ & $\begin{array}{l}39(2 \sigma) \\
61(2 \sigma) \\
96(2 \sigma)\end{array}$ \\
\hline 13_098 & $\begin{array}{l}\text { Nasca Palpa, 2, } \\
\text { geoglyph Pista }\end{array}$ & $434 \pm 74$ & $\begin{array}{l}1440-1511 \\
1572-1622 \\
1415-1643 \\
{[1420-1499]}\end{array}$ & $\begin{array}{l}58(\sigma) \\
35(\sigma) \\
95(2 \sigma)\end{array}$ \\
\hline 13_099 & $\begin{array}{l}\text { Nasca Palpa, } 3 \text {, } \\
\text { geoglyph at a ceme- } \\
\text { tery }\end{array}$ & $426 \pm 80$ & $\begin{array}{l}1444-1512 \\
1566-1623 \\
1409-1652 \\
{[1475-1633]}\end{array}$ & $\begin{array}{l}58(\sigma) \\
38(\sigma) \\
95(2 \sigma)\end{array}$ \\
\hline 13_101 & $\begin{array}{l}\text { Nasca Palpa, 5a, } \\
\text { Mandala (fake) }\end{array}$ & $-2086 \pm 77$ & $\begin{array}{l}1962,7-1963,5 \\
1977,7-1982,2 \\
{[1978-1980]}\end{array}$ & $\begin{array}{l}8(2 \sigma) \\
87(2 \sigma)\end{array}$ \\
\hline 13_102 & $\begin{array}{l}\text { Nasca Palpa, } 5 \text { b, } \\
\text { Mandala (fake) }\end{array}$ & $-2557 \pm 77$ & $\begin{array}{l}1963.5-1963.9 \\
1974.1-1978.1 \\
{[1973-1976]} \\
\end{array}$ & $\begin{array}{l}10(2 \sigma) \\
85(2 \sigma)\end{array}$ \\
\hline 13_103 & $\begin{array}{l}\text { Nasca Palpa, } \\
\text { Cantalloc } 6, \\
\text { ash (Nasca period) }\end{array}$ & $1829 \pm 82$ & $\begin{array}{l}131-185 \\
196-343 \\
47-419 \\
{[204-369]}\end{array}$ & $\begin{array}{l}25(\sigma) \\
75(\sigma) \\
95(2 \sigma)\end{array}$ \\
\hline
\end{tabular}

appropriate to note here that Cantalloc, with its huge geoglyph known as 'Needle and Thread', was investigated already by M. Reiche and that the Quechua place name Cantalloc means 'place of weaving' [3].

e) the sample $13-104$ (not listed in the table) was too small for the standard ${ }^{14} \mathrm{C}$ analysis, only the AMS method was used. This sample contained small light ears of corn. AMS analysis has proven that this is a very old sample - it comes from 330-480 CE.

\section{Conclusions}

At least a part of the geoglyphs (geometric features and figures) on the Nasca plateau near the towns Nasca and Palpa (and possibly many others) are traces of ropemaking manufactories, producing the required range of rope and net products for fishermen and raft makers through the long ages. The narrow triangular sectors are tidied areas for ropemaking, the rectangular areas being used possibly for making nets. The trapezoids with long zigzag lines across them are where long ropes were produced in relatively small areas. The longest straight lines might be traces of the manufacture of very long strings, connecting paths for pedestrians or delineated boundaries of claimed areas. The images of animals and various symbols running 
out of the work areas can be logos (totems) of the different ropemaking workshops on pampa, made to be seen from above, the place of the presumed afterlife. This is the substance of Sonnek hypothesis [17], in some aspects very technical, in others speculative; the hypothesis has been tested here. We support it.

The important fact is that the new hypothesis is not in conflict with the older ones. It is well possible that certain lines were created with intentional astronomical meaning as well as practical utility, nor is a combination of practical use with a ritual/ceremonial one ruled out. As for the existence of drinking groundwater, its proximity was certainly welcome by the ropemakers. It is not a problem for the newly presented hypothesis to explain the diverse directions of the geoglyphs, their overlapping, their presence in areas with possible groundwater, and the long lines and rays.

Radiocarbon age estimates of pieces of wood and other material at the geoglyphs near Nasca (Cantalloc) and Palpa (Pista, Mandala) indicate a wide range from early Nasca to the $17^{\text {th }}$ century (excluding one present-day fake glyph - the Mandala), see the Table and $[20,11]$. This supports, but does not prove, the new hypothesis; these wooden samples may be as old as the rope factories.

One of the huge geoglyphs on the pampa near the town of Nasca, well known as El Astronauto, has been studied with the conclusion that this glyph probably depicts a fisherman (fitting that area, with its fish and agricultural product exchange, much better than an astronaut) $[18,8]$.

Moreover, in the quechua language the word huasca (wasca, waskha) means a rope; it sounds similar to nasca. This becomes very interesting now in context with the new Sonnek hypothesis. Also the name Cantalloc (an archaeological site near Nasca) should be mentioned, because it means the 'place of weaving' [3].

\section{References}

[1] Teofilo Laime Ajacopa et al. Diccionario Bilingüe Iskay simipi yuyayk'ancha "Quechua - Castellano, Castellano - Quechua". La Paz, Bolivia: AGRUCO-Obras generales, 2007.

[2] Anthony F. Aveni. Between the lines: the mystery of the giant ground drawings of ancient Nasca, Peru. Austin: University of Texas Press, 2000.

[3] Evan Hadingham. Lines to the Mountain Gods-Nazca and the Mysteries of Peru. University of Oklahoma Press, 1988, p. 307.

[4] Karolína Hanzalová and Karel Pavelka. "Documentation and virtual reconstruction of historical objects in Peru damaged by an earthquake and climatic events". In: Advances in Geosciences 35 (2013), pp. 67-71. DOI: 10.5194/adgeo-35-67-2013.

[5] David Johnson. Beneath the Nasca Lines and Other Coastal Geoglyphs of Peru 8 Chile. Poughkeepsie, New York: Global Learning Inc., 2010.

[6] David Johnson, Donald Proulx, and Stephen B. Mabee. In: Andean Archaeology II Art, Landscape and Society. Ed. by Helaine Silverman and William H. Isabell. Kluwer Academic/Plenum Publishers, 2002. Chap. The Correlation Between Geoglyphs and Subterranean Water Resources in the Rio Grande de Nasca Drainage, pp. 307-332.

[7] Jaroslav Klokočník and Karel Pavelka. "Nasca, Peru: Der "Astronaut" ist ein Fischer". In: AmerIndian Research 5/2.16 (2010). In German, pp. 112-114. 
[8] Jaroslav Klokočník et al. "Los Geoglifos de Nazca, Perú". Spanish. In: BIRA: Boletín del Instituto Riva-Agüer 29 (2002). In Spanish, pp. 13-29.

[9] Paul Kosok. Life, land and water in ancient Peru. New York: Long Island University Press, 1965.

[10] Laura Ladrón de Guevara de Cuadros. Diccionario Quechua. Lima, Peru: Editorial Brasa, 1998, p. 838.

[11] Karel Pavelka. "The dating of organic findings from the expedition in Peru in 2012 (Datování organických nálezů z expedice Peru 2012)". In: Sborník studentské vědecké konference. Ed. by Karel Pavelka. CTU, Faculty of Civil Engineering. Telč, 2014.

[12] M. Reiche. Mystery on the Desert: Nazca, Peru. In, English, German and Spanish. Re-issued October 1996. Lima, Perú: Association Maria Reiche for the Lines of Nasca, 1949.

[13] C. Richter. "Nasca GIS - An Application for Cultural Heritage Conservation". In: Proceedings of the Nasca Symposium 2006. Ed. by B. Teichert and C. Rust. Dresden: HTW, 2007, pp. 115-126.

[14] K Schreiber. "The Water System of the Nasca Culture". In: Proceedings of the Nasca Symposium 2006. Ed. by B. Teichert and C. Rust. Dresden: HTW, 2007, pp. 43-54.

[15] Jiří Sonnek. Jiři Sonnek - detail výroba lana (planina Nazca). URL: https : //www . youtube.com/watch?v=QJe6sCVJ6Ns (visited on 09/03/2016).

[16] Jiří Sonnek. Jiř́ Sonnek - detail výroba lana (planina Nazca). URL: https : / / www . youtube. com/watch?v=DdjjAbjUbkE (visited on 09/03/2016).

[17] Jiří Sonnek. "Planina Nazca bez záhad (The Nasca Plains without Mysteries)". Czech. In: Živá archeologie 13 (2011), pp. 63-67.

[18] Jiří Sonnek and Jaroslav Klokočník. "Der Fischer auf der Pampa von Nasca in Peru: neue Ergebnisse". In: AmerIndian Research 9/1.31 (2014), pp. 112-114.

[19] Henri Stierlin. Nazca: La Cle du mystere: Le dechiffrement d'une enigme archeologique (French Edition). Albin Michel, 1983.

[20] I. Světlík. The results of radio-carbon dating findings from the expedition Perú 2012 by AMS method (Výsledky radiouhlíkového datování nálezi̊ z expedice Perú 2012 metodou $A M S$ ). Tech. rep. 6.12.2013 (in Czech). Institute of Nuclear Physic, Czech Academy of Science, 2015, p. 13.

[21] B Teichert. "Astronomical investigations of the Nasca Line". In: Proceedings of the Nasca Symposium 2006. Ed. by Teichert and C. Rus. Dresden: HTW, 2007. 2007, pp. 87-101. 